\title{
Imagens irônicas: o casamento ficcional entre a presidenta e o ministro
}

\author{
Ironic images: the fictional wedding between \\ the president and the minister
}

\section{Ivan Vasconcelos Figueiredo}

Doutorando em Estudos Linguísticos da Universidade Federal de Minas Gerais (UFMG), mestre em Letras pela Universidade Federal de São João Del Rey (UFSJ) e bacharel em Comunicação Social/Jornalismo pela Universidade Federal de Viçosa (UFV), São José dos Campos, SP - Brasil, e-mail: ivanfigueiredo@gmail.com

\section{Resumo}

O artigo realiza um ensaio com a análise sobre a paródia jornalística da relação "político-amoroso", de cunho ficcional, entre a presidenta do Brasil, Dilma Rousseff, e o, então, ministro do Trabalho, Carlos Lupi, veiculada pelo blog The Piani Herald, em novembro de 2011. O estudo debate a geração do efeito de ironia a partir da reconstrução de estereótipos, emblemas e mitos, entendidos na visão de Boyer (2008) como esquemas cristalizados de acesso aos imaginários sociais. O quadro teórico metodológico é fundamentado na inter-relação entre a grade de análise de imagens proposta por Mendes (2010) e as proposições de Boyer (2008) para sistematização do estudo dos imaginários sociais. A evocação e a transgressão de conhecimentos estáveis socialmente partilhados atuam como facilitadores da comunicação entre o veículo e o público-alvo, desconstruindo imagens prévias relacionadas à Dilma e ao Lupi. Na perspectiva paródica, a presidenta $e ́$ equiparada ao imaginário de realeza, de quem governa, bem como a de princesa solitária que encontra seu príncipe.

Palavras-chave: Imaginários sociais. Paródia. Jornalismo.

\section{Abstract}

This paper wants do analyze of journalistic parody about the fictional relationship "political and affectionate" between the President of Brazil, Dilma Rousseff, and, the Labor Minister, Carlos Lupi, conveyed by the blog The Piauí 
Herald in November 2011. The study discusses the creation of irony's effect from de reconstruction of stereotypes, myths and symbols, understood in Boyer's (2008) perspective, as crystallized schemes of access to social imaginary. The theoretical and methodological framework is based on the interrelationship between of image analysis grid proposed by Mendes (2010) and Boyer (2008) notions, in order to systematize the social imaginaries study. The evocation and transgression of stable and shared social knowledge act as an communication enabler between the media and target audience, deconstructing previous images related to Dilma and Lupi. In parodic perspective, the president is equated to royalty imaginary, who governs, and the lonely princess who finds her prince.

Keywords: Social imaginaries. Parody. Journalism.

\section{Introdução}

O presente artigo realiza um ensaio com a análise da paródia jornalística nas dimensões verbal e icônica, discutindo como estereótipos, emblemas e mitos podem atuar como simplificadores estáveis de conhecimento social, visando à identificação da transgressão de gênero e de estatuto, a associação e ruptura com outro enunciado já dado, gerando, assim, efeitos de humor. O material de análise é formado pela postagem do blog The Piaui Herald denominada "Dilma confessa que também ama Lupi e marca casamento", publicada em 11 de novembro de 2011, sendo associado a duas notícias factuais veiculadas pelo jornal Folha de S. Paulo nos meses de novembro e dezembro. A investigação está focada no título, legenda e foto-montagem, entendidos como elementos de captação do público-alvo e construção dos primeiros sentidos do discurso paródico.

O quadro teórico-metodológico está alicerçado na inter-relação entre a grade de análise de imagens desenvolvida por Mendes (2010) e as proposições de Boyer (2008) para sistematizar a investigação das três formas de cristalização de imaginários sociais.

A grade permite o estudo do icônico dentro do quadro da Teoria Semiolinguística de Charaudeau (2009), aliada aos estudos de Aumont (1993) sobre o icônico, as considerações de Guimarães (2004) acerca das cores, entre outros autores. A primeira dimensão a ser investigada na imagem é a situacional, que revela as condições do contrato de comunicação midiático. Os aspectos técnicos da imagem fixa fornecem dados de apoio para analisar a terceira dimensão (discursiva), colocando em voga os modos de organização do discurso icônico, os imaginários sociodiscursivos, as categorias etóticas e patêmicas.

Para fins do presente estudo, opta-se por substituir a noção charaudeana de "imaginários sociodiscursivos" pela de "imaginários sociais" de Boyer (2008). Compreende-se que esta opção metodológica permite aprofundar o conhecimento das três formas de cristalização de imaginários (estereótipo, emblema e mito). Cabe ressaltar que os imaginários, tal como compreende Charaudeau (2007), não são formados somente por estruturas fixas e estáveis, abarcando saberes de conhecimento e de crença.

Segundo Boyer (2008, p. 100), os campos da sociolinguística, psicologia social, semiótica e análise do discurso midiático procuram esclarecer o conhecimento que podemos ter do imaginário coletivo e de que modo este funciona na esfera social. As variadas formas de investigação ocasionam, para Charaudeau (2007, p. 49), profusão de termos que levam a uma confusão conceitual. Assim, conceitos como clichê, lugar comum, pré-julgamento, ideias formatadas, estereótipo, emblema e mito são utilizados para tentar explicar os saberes simplificados e estáveis que servem de base para a doxa (campo sociodiscursivo das crenças e opiniões comuns).

Para sistematizar o estudo desses processos de cristalização, Boyer (2008) esboça um modelo transdisciplinar que evidencia as três modalidades distintas de semiotização do mundo - estereótipo, emblema e mito, as quais operam a partir de dois níveis de cognição social, a categorização (estereotipagem) e simbolização (emblematização, mitificação), possuindo a mídia como elemento central de seleção e difusão de discursos. 
Os imaginários coletivos, na proposta de Boyer (2008), dialogam com as esferas midiático-culturais e os objetos sociais, além disso, têm como pano de fundo as representações partilhadas, constituintes das ideologias. As duas formas de cognição social determinam os caminhos da cristalização proposta para os processos de semiotização midiática: estereotipagem, emblematização e mitificação. A promoção midiática e encenação discursiva ocorrem por meio de estereótipos, emblemas e mitos.

Cabe ressaltar que, em seu percurso analítico, Boyer (2008) trata das representações como elementos constituintes dos imaginários coletivos, não aprofundando na discussão conceitual dos termos. Adota-se aqui a compreensão de Charaudeau (2007, p. 53), na qual o imaginário social se faz no domínio da prática social, sendo um modo de apreensão do mundo que nasce da mecânica das representações sociais. Os imaginários resultam, então, de um processo de simbolização do mundo da ordem afetivo-racional e têm dupla função de criação de valores e de justificativa da ação.

Para Boyer (2008, p. 101), o imaginário, "noção camaleão no domínio das ciências humanas e sociais", nutre de conteúdo os imaginários individuais e tem existência em determinada cultura ou grupo, tendendo a certa cristalização. A base de sustentação está na ideologia (rede de representações interconectadas que envolve relações de poder) e nas representações, as quais possuem estrutura complexa e dinâmica.

O estereótipo, segundo Boyer (2008), nasce do processo de cristalização da estereotipagem, por meio da categorização do mundo, originada na identificação, classificação, etiquetagem. "Le stéréotype est ici consideré comme une sorte de représentation que la notoriété, la fréquence, la simplicité ont imposée comme évidence à l'ensemble d'une communauté (ou d'un groupe à intérieur de la communauté)"1 (BOYER, 2008, p. 102). Essa forma simplificada de conhecimento socialmente partilhado possui a função econômica na cognição social, a fim de estabelecer a comunicação e preencher a função identitária em determinada comunidade ou grupo. $\mathrm{O}$ acesso a esse conjunto cristalizado e compacto faz com que o sujeito produza sentidos. Mais do que proporcionar um conforto identitário tal como entende Boyer (2008), Amossy (1991, p. 101) afirma que o estereótipo deforma o real e impõe forma e sentido pré-fabricados, podendo ser consumido passivamente e naturalizado ou ser percebido como esquema cultural e denunciado. Além disso, a categorização pode atuar tanto positivamente quanto negativamente.

Mediante o processo de cognição social denominado "simbolização" (distinção, sentido outro que é dado a um signo), o emblema é compreendido por Boyer (2008) como pertencente à ordem da fixação representacional. Este esquema opera sobre seus atores e produtos culturais, apoiando-se em um singular notório e significativo que encarna o geral.

Por fim, o mito funciona fora do padrão, pela exemplaridade indiscutível, transcendendo a história e a moralidade. Com estrutura dinâmica, o mito "moderno" só se cristaliza quando a imagem completada e familiar escapa do dilema da naturalização ou do reconhecimento crítico, aponta Boyer (2008). A personagem mitificada é objeto de uma "valorização positiva quase incondicional", de uma sublimação e de um autêntico culto (oficial), diz Amossy (1991, p. 101).

Nas sociedades contemporâneas, estereótipos, emblemas e mitos têm os meios de comunicação como principais difusores. Tais elementos facilitam a comunicação entre os sujeitos e a paródia midiática, ao justapor discursos anteriores em um "novo" dizer, utiliza-se dessa simplificação de saberes como estratégia de economia cognitiva para construção dos efeitos de sentido da ironia. Machado (2001, p. 4) esclarece que

o texto paródico possui, ao mesmo tempo, as vozes do texto $\mathrm{A}$ (texto de origem) e as vozes do texto $B$ (texto paródico propriamente dito). O texto paródico nunca oculta totalmente o texto parodiado. $\mathrm{O}$ texto de origem

\footnotetext{
Tradução livre: “O estereótipo é aqui considerado como um tipo de representação em que a notoriedade, a frequência e a simplicidade são impostas como evidência ao conjunto de uma comunidade (ou de um grupo ao interior de uma comunidade)".
} 
deve sempre estar presente de algum modo, justaposto ao novo. Desse modo, a paródia, entre outras coisas, propicia um diálogo entre diferentes textos e diferentes sujeitos.

Assim, ao retomar vozes anteriores para (re)construir o dizer, a paródia apoia-se em sentidos cristalizados socialmente para que os efeitos de transgressão e ironia possam ser mais bem percebidos pelo receptor.

\section{O casamento ficcional da presidenta com o ministro}

O blog The Piani Herald é uma publicação virtual da revista Piauí, pertencente ao grupo midiático brasileiro O Estado de São Paulo. O diário eletrônico insere-se em um "contrato de diversão", compreendido na definição de Machado (2001, p. 2), procurando "amenizar a leitura de temas 'duros' e que são, no entanto, o espelho (mais ou menos fiel, mais ou menos deformado) do que está acontecendo em nossas cidades, no nosso país ou no mundo". A estratégia está baseada na construção de paródias, associando dois ou mais assuntos largamente difundidos pela mídia, subvertendo o gênero em um jogo ficcional de humor. O blog procura apresentar-se, assim, como entretenimento, em complementação a uma revista de jornalismo literário que se qualifica "para quem gosta de ler" (PIAUÍ, 2006).

A instância produtora é compósita, sendo formada pelo grupo empresarial O Estado de São Paulo, a revista Piaui, o blog em si, os redatores, os fotógrafos, os editores do site e das fotos montagens e as celebridades presentes nas fotografias, bem como os veículos que foram utilizados para a paródia.

O texto tem como Eu-enunciador e uma das vozes do blog The Piaui Herald. O gênero é situacional, conforme observa Charaudeau (2004), e o estatuto é ficcional, procurando gerar efeitos de ficção e de gênero factual, em que há a construção de ilusão de que o texto é uma notícia séria quando, no entanto, é uma notícia humorística.

A paródia (FIG.1) faz alusão ao casamento fictício, de cunho "político-amoroso", entre a presidenta do Brasil (mandato 2010-2014), Dilma Rousseff, e, o então, ministro do Trabalho, Carlos Lupi. Na composição visual da fotografia, Dilma e Lupi aparecem com os rostos recortados e sobrepostos ao retrato oficial do casamento da monarquia britânica, ocorrido em 29 de abril de 2011, entre o príncipe William Windsor e a duquesa Kate Middleton (Figura 2).

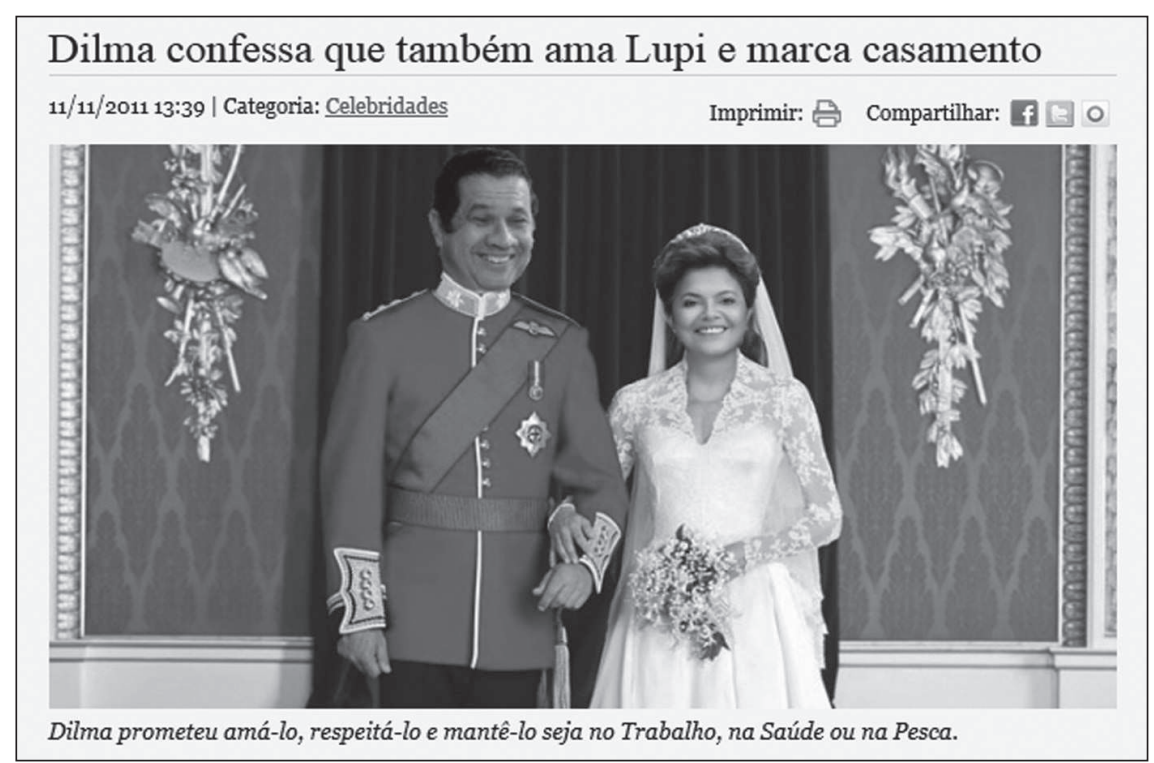

Figura 1 - Paródia de casamento entre a presidenta e o ministro do Trabalho Fonte: The Piauí Herald (2011). 


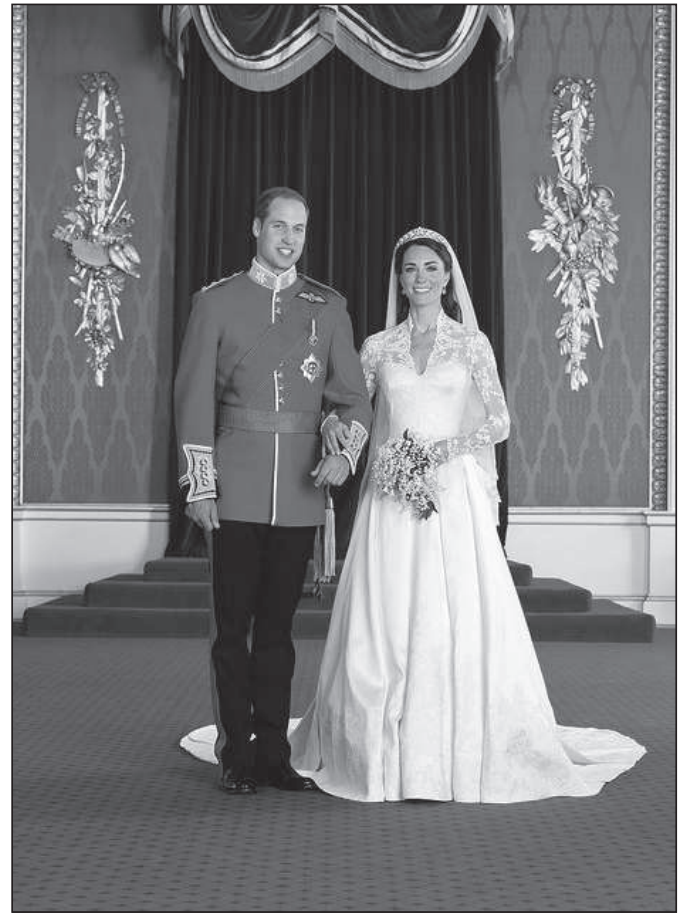

Figura 2 - Foto tirada pela imprensa da realeza britânica. A legenda oficial diz: “The Royal Wedding at Buckingham Palace on 29th April 2011: The Bride and Groom, TRHThe Duke and Duchess of Cambridge in the Throne Room", Fonte: British Monarchy (2011).

\section{A foto-montagem do blog The Piauí Herald} opera na assimilação rápida e fácil dos sentidos pretendidos pelo enunciador. O olhar do leitor é direcionado a dois enunciados. O primeiro traz, mediante o processo de simbolização, a exaltação do mito do casamento real (e também da união do conto de fadas) ao apresentar as vestimentas, os corpos e o cenário da cerimônia ocorrida na corte inglesa e difundida pela mídia (Figura 2), gerando uma noção do contexto. O espectador pode resgatar, assim, traços de saberes de conhecimento em uniões monárquicas espetacularizadas pelos meios de comunicação em larga escala, tais como: o enlace entre Gracie Kelly e o príncipe de Mônaco, Rainier III, em 1956; Lady Diana e o príncipe de Gales, Charles Windsor, em $1981^{3}$.

Na Figura 2, o príncipe William e a duquesa Kate são enquadrados em plano aberto em frente à Sala do Trono, local utilizado pela monarquia britânica para ocasiões especiais, como Jubileus a rainha em 1977 e 2002. "Another use of the Throne Room has been for formal wedding photographs ${ }^{4 "}$ (THE BRITISH MONARCHY, 2011), a partir do século XX, abrigando o casamento real, em 1947, entre a princesa Elizabeth e o duque de Edimburgo, Philip Mountbatten. De acordo com a descrição oficial do governo britânico, o prédio foi construído pela rainha Elisabeth I entre os anos 1853-55 para abrigar um amplo espaço de entretenimento ao palácio. Ao longo do reinado da rainha Vitória, o ambiente foi utilizado para encontros do Tribunal e espetáculos de dança.

O ambiente traz dois troféus esculpidos e dourados em 1795, formando figuras aladas da "vitória" em guirlandas acima da "cadeira do estado". De acordo com The British Monarchy (2012), os adornos fazem alusão às quatro estações. A Sala do Trono retrata também episódios triunfais da Guerra das Rosas, dividido em quatro cenas: abaixo dos arcos procênicos, está representada a Batalha de Tewkesbury; na janela oposta, a Batalha de Bosworth Field; sobre as janelas, o casamento de Henry VII e Elizabeth of York (1840).

A pose para a fotografia oficial segue o protocolo de casamentos anteriores, tais como da rainha Elizabeth II com Phillip e do príncipe Charles com Lady Diana. Conforme as Figuras 3 e 4, percebe-se a recorrência de padrões de composição fotográfica, tendo em vista o reconhecimento de

\footnotetext{
2 Tradução livre: "O casamento real no Palácio de Buckingham em 29 de abril de 2011: o noivo e a noiva, o duque e a duquesa de Cambridge na Sala do Trono".

Outras cerimônias difundidas pela imprensa reforçam o reconhecimento rápido e a valoração positiva do mito do casamento real: o príncipe japonês Akishino e a princesa Kiko (1990); o príncipe da Jordânia, Abdullah e a esposa Rania (1993); o príncipe da Bélgica, Phillipe, e a princesa Mathilde (1999); o herdeiro do trono espanhol, o príncipe das Astúrias, Don Felipe de Borbón y Grecia, com Leticia Ortiz (2004).

${ }^{4}$ Outras cerimônias difundidas.
} 
modelos e valores veiculados anteriormente, os quais são projetados para percepção do público diante da fotografia de William e Kate, assim como na paródia envolvendo Dilma e Lupi.

Mais do que uma simples união oficial entre um casal, a pompa da cerimônia, explica Parry (2007, p. 47-48), faz parte dos ritos necessários à corte para manter a imagem de desempenho e soberania: "In all ages, monarchy necessarily involves performance; successfull sovereigns are icons. But they are iconic at a number of levels, and beneath the surface images lies a broader and deeper political and constitucional context $[\ldots] "$...

O ato de dar visibilidade midiática a eventos especiais da monarquia inglesa é uma "invenção da tradição", aponta Cannadine (1983), que funcionou no século XX como forma de distração e conforto da população nos períodos das grandes guerras mundiais. Desde 1935, "every royal jubilee, coronation, major wedding and wedding anniversary (but not, significantly, births or funerals) bas been the subject of a special issue. Once more, it was an innovation; but well within 'traditionals' moulds" (CANNADINE, 1983, p. 155). O ar festivo é complementado com feriados decretados nas datas comemorativas da realeza britânica, ressalta Parry (2007, p. 71). Os rituais realizados pela realeza britânica são construídos como cerimoniais públicos com o intuito de transmitir os sentidos pretendidos pela corte aos espectadores. Além disso, as cerimônias - tais como os casamentos reais e grandes eventos religiosos, políticos e esportivos - são caracterizadas pelo que Dayan e Katz (1994, p. 16-32) denominam "norma de visualização", na qual uma pessoa conta à outra que aquele acontecimento histórico deve ser presenciado, mesmo que midiaticamente. Tal procedimento integra a sociedade em um sentimento comum capaz de legitimar a autoridade do evento-espetáculo difundido em larga escala pelos meios de comunicação.
Com base nesse contexto de casamento de porte monárquico, o blog The Piani Herald constrói a paródia por meio da sobreposição imagética das faces de Lupi e Dilma sob os rostos do príncipe e da duquesa.

O meio de comunicação retoma o episódio em que o então referido ministro foi denunciado pela imprensa brasileira por prática de corrupção na pasta que comandava. Diante das acusações, conforme noticiado pela Folha de S. Paulo (2011a), Lupi disse no dia 8 de novembro de 2011 que só sairia do ministério "abatido à bala. Dilma me conhece. Eu duvido que ela me tire". O depoimento não agradou à presidenta. Em retratação durante explicações na Câmara dos Deputados, o ministro afirmou que pedia desculpas: "Dilma, eu te amo", informou a Folha de S. Paulo (2011b). A partir desses acontecimentos reportados pela mídia e aqui mostrados por trechos da cobertura realizada pela Folha, o blog The Piani Herald construiu a notícia ficcional "Dilma confessa que também ama Lupi e marca casamento".

A manchete direciona a primeira construção de sentidos por parte do leitor e já apresenta uma ruptura de um imaginário construído sobre ela que criaria uma imagem de "mulher solitária" e "masculinizada"-imagens categorizadas advindas do processo de etiquetagem e atribuídas a vários ethé da presidenta Dilma Rousseff construídos pela mídia. A presidente é, assim, rotulada como mulher muito independente e líder autoritária e que, por isso, não consegue um par; porém, na construção humorística do blog, Dilma, enfim, encontrou Lupi. O suposto ar confessional da declaração de Dilma Rousseff é contrastado com a encenação icônica da foto dos "recém-casados", dado na representação da valoração positiva quase incondicional do mito do casamento de "contos de fada" entre um príncipe e uma pebleia.

O segundo enunciado retoma a relevância da face como reconhecimento do outro, em que o receptor está diante rostos de Dilma e Lupi, porém,

\footnotetext{
${ }^{5}$ Tradução livre: "Em todas as idades, monarquia envolve, necessariamente, performance/desempenho; soberanos bem-sucedidos são ícones. Mas eles são ícones em vários níveis e, por trás das imagens da superfície, encontram-se um amplo e profundo contexto político e constitucional".

Tradução livre: "Todo Jubileu real, coroação, grande casamento e aniversário de casamento (mas não, significativamente, os nascimentos e funerais) tem sido objeto de uma emissão especial. Mais uma vez, foi uma inovação, porém, dentro dos moldes 'tradicionais"'.
} 


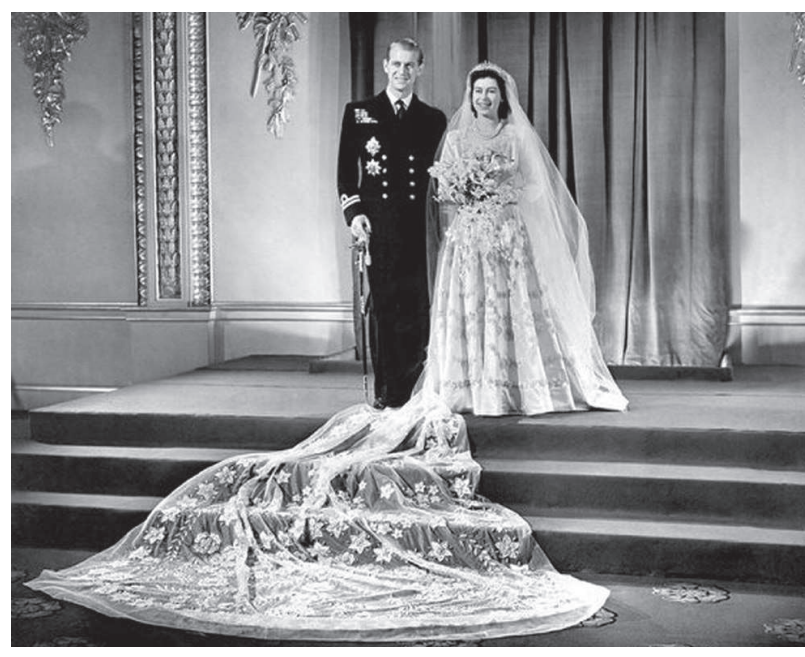

Figura 3 - Casamento entre a rainha Elizabeth e o duque Phillip, em 1947. Pose oficial na Sala do Trono

Fonte: National Geographic (2012).

de forma ficcional pela presença das marcas da edição fotográfica.

O jogo entre universo factual e ficcional na fotografia lança pistas (sobre o Tu-destinatário) para que o Tu-interpretante perceba, de modo mais atento, a dimensão técnica da imagem. Para Aumont (1993, p. 137), “o espectador não percebe apenas, na imagem, o espaço representado, percebe também como tal o espaço plástico que é a imagem”. Desse modo, a superfície e sua forma de organização, a gama de valores, a gama de cores e a matéria própria da imagem permitem a percepção do contexto e ambientação registrados iconicamente.

A foto-montagem de Dilma na posição de plebeia, noiva e "futura" duquesa contrasta com a de Lupi como príncipe, coronel militar e noivo, em um casamento típico da realeza britânica. A composição é marcada por relação geométrica triangular, remetendo a traços presentes em pinturas da Renascença (entre os séculos XIII e XVII), com os corpos na centralidade da cena. $\mathrm{O}$ fundo avermelhado com brasões em ouro contextualiza um palácio, no caso, o de Buckingham, residência oficial da monarquia britânica, em Londres, Inglaterra.

Como observa Guimarães (2004, p. 114), a carga emocional do vermelho é atravessada pelos três códigos constituintes das cores. Utilizada desde o Império Romano, a cor remete à nobreza e realeza, estando presente nos mantos de reis, por exemplo.

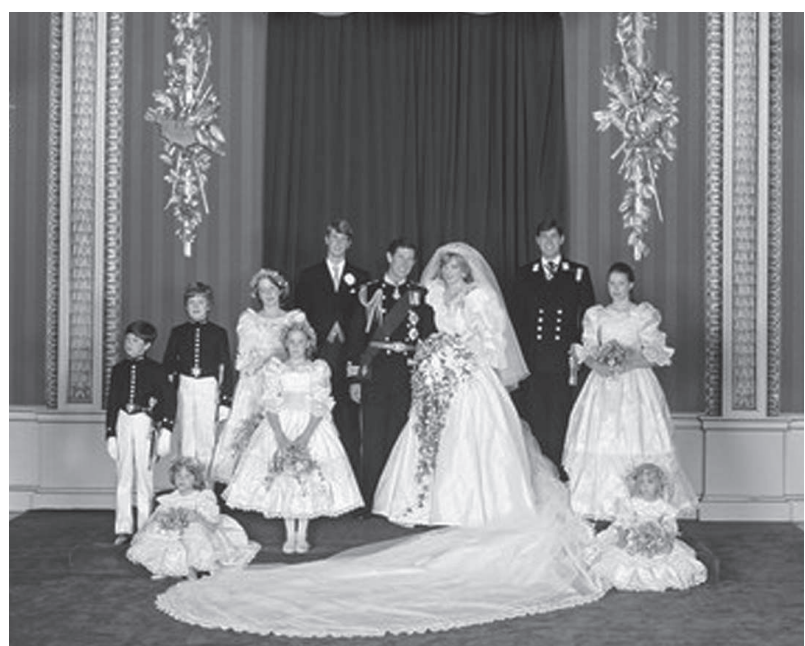

Figura 4 - Casamento do príncipe Charles e Diana, em 1987 Fonte: The Star (2012).

Na situação do casamento real parodiado, a tonalidade pode evocar ainda sensos de fogo, violência e poder. A tonalidade compõe a parede do prédio e a farda de gala utilizada pelo príncipe, inserindo-o na posição de poderio militar e governamental. $\mathrm{O}$ amarelo do ouro e dos adornos das roupas faz alusão ao sol e o branco do vestido da esposa traz a noção socialmente partilhada de pureza. As composições, em pixels, dos rostos recortados e o cenário revelam luminosidades distintas que trazem as marcas da edição: na foto oficial do casamento, a iluminação uniforme procura privilegiar as pessoas da cena e o ambiente, sem relegar a parede e adornos ao fundo. Já as faces de Dilma e Lupi recebem iluminação diferenciada, direcionada ao rosto e advindas de outras cenas enunciativas.

Ao associar a presidenta e o ministro ao matrimônio real, as personagens incorporam traços do discurso britânico, porém de modo deformado pela paródia. Se a relação política entre Dilma e Lupi é de suposta submissão hierárquica dele, com a utilização do emblema de poder de um príncipe, o ministro passa a ser o príncipe que comanda a duquesa.

$\mathrm{Na}$ análise do discurso de posse de Dilma na presidência, Vitale (2011) afirma que Rousseff expressa o poder da mulher, a partir da enunciação "sim, a mulher pode", posicionando-se como líder política da envergadura de Barack Obama, em uma 
alusão ao slogan da campanha política norte-americana "Yes, we can". Dilma constrói seus ethé recorrendo também ao estereótipo da mãe, da mulher que cuida. Ao incluir uma sequência epidítica ao seu antecessor, o ex-presidente Luiz Inácio Lula da Silva, a presidenta pretende criar ainda a imagem de governante tolerante e, respondendo às críticas da imprensa, procura reforçar o ethos de liderança democrática que protege a liberdade plena.

Por meio da associação à estereotipia de noiva como "fiel/casta", "subordinada" e "pura", o blog The Piaui Herald procura romper com o ethos de competência de Dilma ao justapor crenças sociais vinculadas ao papel feminino no casamento. O efeito de humor estabelece-se, parcialmente, no deslocamento de Dilma como mulher que possui poder e meios para exercê-lo, o que garantiria uma circulação mais fácil na esfera pública dominada pelos homens. Assim, o veículo humorístico apresenta a fraqueza da presidenta, o amor, em contraposição às suas características nomeadas midiaticamente de fria, feminista, masculinizada. Ao ser capaz de amar, Dilma insere-se em um contrato de submissão ao outro. Na paródia, o casamento de contos de fadas é evocado juntamente com a expectativa de passividade vinculada ao papel feminino.

Os sentidos projetados pela foto-montagem também são associados àqueles exaltados pela legenda: "Dilma prometeu amá-lo, respeitá-lo e mantê-lo seja no Trabalho, na Saúde ou na Pesca". A partir da construção paródica do ritual do casamento como juramento de um contrato legal, o enunciado de promessa de fidelidade resgata do mito do amor romântico preconizado pelas religiões cristãs ocidentais, reforçado por discursos sociais, e evidenciado na paródia da frase de concretização do matrimônio, em que a ruptura está em "mantê-lo seja no Trabalho, na Saúde ou na Pesca”. Cabe ressaltar que o enunciado acima é polifônico, evidenciando que Dilma ama e retomando a declaração de Lupi; coloca-se, assim, a posição de Dilma como correspondendo ao amor do ex-ministro. O blog infere, por meio de um jogo de pressupostos e subentendidos, sobre a permanência de Lupi como ministro do governo, em uma acomodação de interesses políticos, no qual a fidelidade do matrimônio se revela como compromisso político no espaço público, em uma relação ficcional de nepotismo. Cabe lembrar que Lupi foi o sexto ministro denunciado por corrupção no primeiro ano de mandato da presidenta.

Com os modos de organização narrativos e argumentativos do discursivo icônico e verbal, o efeito paródico da postagem coloca em xeque a moralidade do jogo político no Brasil e as relações de interesse que envolvem o exercício do mandato no Executivo Nacional, ao resgatar e reconstruir esquemas de cristalização dos imaginários sociais por meio dos processos de categorização e simbolização. O contrato de diversão procura ainda "brincar" com a desconstrução do ethos de competência da mulher, ao qual a presidente se ancora para ser aceita como a primeira chefa de uma esfera de poder marcadamente masculina.

\section{Considerações finais}

A breve análise realizada no presente estudo evidencia como as formas simplificadas de conhecimento socialmente partilhado podem ser utilizadas como componentes das paródias jornalísticas. Nesse caso, estereótipos, emblemas e mitos atuam como economia cognitiva para reconhecimento rápido do público-alvo do blog, visando ao efeito de ironia dado no enunciado ficcional.

O processo de simbolização atua em consonância com a categorização, com fronteiras híbridas que permitem a quebra de imaginários cristalizados para que a paródia tenha sentido, uma vez que ela se faz na ruptura do texto $B$ evocado pelo A. Como visto, o efeito de ironia ocorre na transgressão de gênero, simulando uma factualidade na notícia ficcional, em que são contrapostas as imagens prévias de competência, ligada à presidenta, com o papel social de submissão previsto para a noiva e esposa da corte da monarquia britânica. No enunciado do blog The Piauí Herald, há uma inversão das relações de poder e ruptura ethé prévios entre Dilma e Lupi, a partir da imbricação ficcional das esferas privada e pública. Em uma perspectiva da

Tradução livre: "Sim, nós podemos". 
paródia, a presidenta é equiparada ao imaginário de realeza, de quem governa, bem como a de princesa solitária que encontra seu príncipe.

O jogo verbo-icônico entre factual e ficcional opera como elemento de entretenimento no contrato comunicacional de diversão. Porém, de modo deformado do real, revela a crítica humorística sobre as relações políticas, partidárias e pessoais presentes no comando da presidência do país.

Apesar de Boyer (2008) não aprofundar o debate conceitual das noções de representação e imaginário social, o modelo transdisciplinar proposto pelo autor abre espaço para a melhor compreensão das três formas de fixação de conhecimentos socialmente partilhados. Todavia, a cristalização não significa que o saber social está posto em definitivo no enunciado, como uma entidade abstrata fora do discurso ou um núcleo central que toma forma sem filtro ou seleção do enunciador. Em qualquer ato de fala, há sempre um processo cognitivo individual que se apropria de traços desses imaginários mais ou menos estáveis, visando à identificação e simplificação da comunicação entre os sujeitos.

\section{Referências}

AMOSSY, R. Les idées recues: sémiologie du stéréotype. Paris: Nathan, 1991.

AUMONT, J. A imagem. Campinas: Papirus, 1993.

BOYER,H.Stéréotype, emblème, mythe. Sémiotisation médiatique et figment représentationnel. Mots. Les langages du politique. Paris, n. 88, novembro, p. 99-113, 2008.

BRITISH MONARCHY. The Official Royal Wedding photographs. Disponível em: < http://www.flickr.com/ photos/britishmonarchy/5671668271/>. Acesso em: 18 dez. 2011.

CANNADINE, D. The Context, Performance and Meaning of Ritual: The British Monarchy and the 'Invention of Tradition', c. 1820-1977. In: HOBSBAWN, E.; RENGER, T. (Orgs.). The invention of Tradition. Cambrigde: Cambrigde University Press, 1983. p. 101-164.
CHARAUDEAU, P. Visadas discursivas, gêneros situacionais e construção textual. In: MACHADO, I. L.; MELLO, R. de. Gêneros reflexões em análise do discurso. Belo Horizonte: NAD/Fale - UFMG, 2004. p. 59-74.

CHARAUDEAU, P. Linguagem e discurso. São Paulo: Contexto, 2009.

CHARAUDEAU, P. Les stéréotypes, c'est bien, les imaginaires, c'est mieux. In: BOYER, H. Stéréotypage, stéréotypes: fonctionnements ordinnaires et mises em scène: langue(s), discours. Paris: Harmattan, 2007. v. 4. p. 49-63.

DAYAN, D.; KATZ, E. Media events: the live broadcasting of history. Cambrige: Harvard University Press, 1994.

EM SESSÃO na Câmara, Lupi critica imprensa e diz amar Dilma. Folha de S.Paulo,10 nov. 2011. Disponível em:<http://www1.folha.uol.com.br/poder/1004511-em-sessao-na-camara-lupi-critica-imprensa-e-diz-amar-dilma.shtml>. Acesso em: 5 dez. 2011b.

GUIMARÃES, L. A cor como informação: a construção biofísica, linguística e cultura da simbologia das cores. São Paulo: Annablume, 2004.

MACHADO, I. L. Paródia, humor e ironia: assim vai interagindo um jornal. Trabalho apresentado no VI CONGRESSO DA ALAB - A linguagem como prática social. Belo Horizonte: ALAB, 2001. v. 1. CD-ROM.

MENDES, E. Publicidade e imagem: uma proposta de estudo. In: GOUVÊA, L. H.M.; GOMES, R. (Orgs.). Anais do II Fórum Internacional de Análise do Discurso: discurso, texto e enunciação. Rio de Janeiro: UFRJ, 2010. p. 92-101.

MINISTRO do Trabalho diz que só deixa governo 'abatido a bala'. Folha de S.Paulo, 8 dez. 2011. Disponível em: $<$ http://www1.folha.uol.com.br/poder/1003461-ministro-do-trabalho-diz-que-so-deixa-governo-abatido-a-bala.shtml>. Acesso em: 5 dez. 2011 a. 
NATIONAL GEOGRAPHIC. Pictures: Royal Wedding as Symbol. Disponível em: <http://news.nationalgeographic.com/news/2011/04/pictures/110428-royal-wedding-dress-kate-middleton-prince-william-gown-designed/>. Acesso em: 5 fev. 2012.

PARRY,J. Whig monarchy, Whig nation: Crown, politics and representativeness 1800-2000. In: OLECHNOWICZ, A (Org.). The Monarchy and the British Nation, 1780 to the present. Cambridge: Cambrigde University Press, 2007. p. 47-72.

PIAUÍ. Encarte promocional enviado para os assinantes da editora Abril, 2006.

THE BRITISH MONARCHY. Buckingham Palace. Disponível em: <http://www.royal.gov. uk/TheRoyalResidences/BuckinghamPalace/ BuckinghamPalace.aspx>. Acesso em: 5 fev. 2012.

THE PIAUÍ HERALD. Dilma confessa que também ama Lupi e marca casamento. nov. 2011. Disponível em: $<$ http://revistapiaui.estadao.com.br/blogs/herald/ celebridades/dilma-confessa-que-tambem-ama-lupi-e-marca-casamento>. Acesso em: 5 dez. 2011.
THE STAR. Catching up with the kids of the historic Charles-Diana Wedding. Disponível em: <http://www. thestar.com/special/article/977846--catching-up-with-the-kids-of-the-historic-charles-diana-wedding $>$. Acesso em: 5 fev. 2012

VITALE, M. A. Las primeras mujeres presidentes en América del Sur. Belo Horizonte: UFMG, 2011. Anotações de palestra.
Recebido: 30/07/2012

Received: 07/30/2012

Aprovado: 16/09/2012

Approved: 09/16/2012 